\title{
Increase in cases of measles in Europe
}

\section{Wzrost zachorowań na odrę w Europie}

\author{
Beata Dziedzic ${ }^{1, D \oplus}$, Ewa Kobos ${ }^{1, E \oplus}$, Zofia Sienkiewicz $^{1, A}{ }^{\oplus}$, Anna Leńczuk-Gruba ${ }^{1, B} \oplus$,

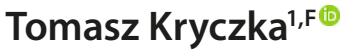 \\ ${ }^{1}$ Department of Nursing, Social and Medical Sciences, Warsaw, Poland \\ A - Koncepcja i projekt badania, B - Gromadzenie i/lub zestawianie danych, C - Analiza i interpretacja danych, \\ $D$ - Napisanie artykułu, $E$ - Krytyczne zrecenzowanie artykułu, $F$ - Zatwierdzenie ostatecznej wersji artykułu
}

Dziedzic B, Kobos E, Sienkiewicz Z, Leńczuk-Gruba A, Kryczka T. Increase in cases of measles in Europe. Med Og Nauk Zdr. 2019; 25(4):

195-199. doi: $10.26444 / \mathrm{monz} / 114382$

\section{Abstract}

Introduction. Measles still remains a serious global epidemiological challenge. The article discusses the problem of epidemiological threats associated with the increasing incidence of measles in Europe in recent years. An exceptionally high contagion index (95\%) of measles is underlined in the characteristics of this disease.

Objective. The aim is to illustrate the epidemiological threat and risk for the European continent associated with the increase in the incidence of measles in recent years.

Brief description of the state of knowledge. The incidence of measles was increasing in the investigated time period. This is thought to be associated with a worsening epidemiological situation in Ukraine, Romania, France, Germany and Italy, which is linked with the failure to implement national immunisation programmes that continue to be the most effective instrument for measles prevention.

Conclusions. There is a certain correlation between the increase in the incidence of measles in the past years and level.of vaccination coverage. Migration from countries with a high percentage of non-vaccinated people and with a high increase in incidence, to countries where measles prevention is superior, is also a source of threat within the evaluated region. Tightening the immunisation system and administration of vaccines to non-vaccinated migrants in the target country seems to be the only solution. It is also extremely important to make parents aware of the safety of vaccination as the most effective protection against infectious diseases.

\section{Key words}

measles, immunisation, eradication, epidemic

\section{Streszczenie}

Wprowadzenie i cel pracy. Odra nadal stanowi poważne globalne wyzwanie epidemiologiczne. W artykule omówiono problem zagrożenia epidemicznego w Europie związanego ze wzrostem zachorowań na odrę w ostatnich latach. W charakterystyce tej choroby zwrócono uwagę na jej wysoki wskaźnik zaraźliwości (95\%). Celem niniejszego opracowania jest przedstawienie problematyki zagrożeń dla sytuacji epidemiologicznej kontynentu europejskiego związanych ze wzrostem zachorowań na odrę w ostatnich latach.

Skrócony opis stanu wiedzy. Zachorowalność na odrę wykazywała w tym czasie tendencję wzrostową. Założono, że jest to związane z pogorszeniem się sytuacji epidemicznej w takich krajach jak: Ukraina, Rumunia, ale także Francja, Niemcy i Włochy, związanej z zakłóceniami w realizacji narodowych programów szczepień.

Podsumowanie. Widoczna jest pewna korelacja między wzrostem zachorowań na odrę w ostatnich latach a poziomem wyszczepienia. Źródłem zagrożeń w analizowanym obszarze może być migracja z krajów o wysokim odsetku niezaszczepionych i o wysokim wzroście zachorowań, takich jak Ukraina czy Rumunia, do państw o mniejszej zapadalności na odrę. Jedynym rozwiązaniem wydaje się uszczelnienie systemu szczepień i objęcie nimi w kraju docelowym tych migrantów, którzy nie byli szczepieni. Niezwykle istotne jest także uświadamianie rodziców o bezpieczeństwie wykonywanych szczepień, stanowiących najskuteczniejszą ochronę przed chorobami zakaźnymi.

\section{Słowa kluczowe}

odra, szczepienia ochronne, eradykacja, epidemia

\section{INTRODUCTION}

Measles still remains a serious global epidemiological challenge. In 2017, there were 110,000 cases of measles worldwide, mainly in children under the age of five years. Widespread immunisation programmes are effective in epidemic prevention, and according to the estimates of the World Health Organisation (WHO), vaccination produced a decline in the incidence of measles by $80 \%$ in $2000-2017$. It also helped prevent approximately 21.1 million deaths [1].

Addres for correspondence: Beata Dziedzic, Department of Nursing, Social and Medical Sciences, Warsaw, Poland

E-mail: beata.dziedzic@poczta.onet.pl

Received: 27.08.2019; Accepted: 19.11.2019; first published: 02.12.2019
In 1984, the WHO adopted an eradication programme of measles, rubella and congenital rubella syndrome (CRS). It was primarily assumed that the endemic foci of this disease would have been eliminated by 2017 and the incidence of CSR would have been reduced to one case per 100 thousand live births by 2010. In Europe, the European Vaccine Action Plan for 2015-2020 assumed complete elimination of foci of measles and rubella. As for measles, this programme seems to be at least threatened [2], as suggested by an increase in the incidence of this disease, as noted in 2017-2018. Currently, more debates are being held on the threat of a new measles epidemic rather than on its eradication. 


\section{OBJECTIVE}

The aim was to illustrate the epidemiological threat and risk for the European continent associated with the increase in the incidence of measles in the past years. The problem was analysed on the basis of epidemiological data from reports and communications of authorities (European Centre for Disease Prevention and Control, as well as from selected literature. The verification was based on a review of Internet websites of public institutions responsible for immunisation programmes in given countries. An attempt is made to shed some more light on the background of this worsening situation, evaluate the functioning of the measles prevention system and consider options to counteract the prevailing situation.

\section{DESCRIPTION OF THE STATE OF KNOWLEDGE}

Disease characteristics of measles. Measles is a highly contagious disease caused by a single-stranded RNA virus of the Paramyxoviridae family and Morbillivirus genus [3]. It is an airborne disease that spreads through the sneezing and coughing of infected people, or through contact with secretions of the infected person, such as saliva or nasal secretions [4]. The contagiousness of measles exceeds 95\% [5], which means that practically all people remaining in the same room with an infected individual will contract the disease.

The incubation of measles takes approximately 10-12 days after exposure. The typical signs and symptoms are manifested for approximately 7-10 days, usually including: high fever (over $40^{\circ} \mathrm{C}$ ), coughing, rhinorrhoea and conjunctivitis [4]. On day 2-3 of the disease, small white spots, known as Koplikıs spots, appear on the mucosa of the cheeks at the level of lower molars $[6,7]$. The typical rash starts on day 14 and lasts for 3-4 days. A red, flat rash initially develops on the face and then spreads to the rest of the body. This period is characterised by the return of a high fever. The patient's condition deteriorates, with more severe signs and symptoms of upper respiratory tract infection $[8,4]$.

Upon recovery, the patient is fully immune. However, measles can cause complications. They mainly develop in immunocompromised or generally neglected children and in children with developmental defects. Measles may cause: gastrointestinal disorders, pneumonia (1-6\% of cases; high mortality), myocarditis, encephalitis ( 1 per 1,000 cases; mortality rate of $15 \%$ and permanent neurological deficits in $25 \%$ of patients), subacute sclerosing panencephalitis (1-4 per 100 thousand cases; it is a delayed complication that may appear several years after recovery from measles and is manifested with speech disorders, dementia, myoclonus and paresis), inclusion-body encephalitis and ophthalmological diseases: keratitis and retrobulbar optic neuritis leading to blindness. Women may suffer miscarriages $[8,4]$.

Measles epidemiology. The mortality rates of measles depend on the region in the world. They do not exceed $0.01 \%$ in developed countries, but may reach even $5 \%$ in developing countries, with infant mortality in the latter amounting to as much as $30 \%$ [4]. In the past several years, the threat of measles in Europe has increased, as has been indicated earlier. Data showing the incidence are presented in Table I.
The deteriorating epidemiological situation concerning measles is mainly driven by a sudden increase in its incidence in the developed countries of Western Europe: France, Germany, United Kingdom and Italy, as well as in Romania. The problem increased throughout the entire decade (2008 4298 cases; 2012 - 8321 cases; 2015 - 3969 cases; 2017 - 4238 cases; 2018 - 9872 cases).

In February 2019, a new measles focus was noted in France in a popular ski resort in Val Thorens. Five new confirmed cases and twenty suspected cases were recorded. New cases of measles observed in Denmark, United Kingdom and Belgium are thought to be linked with this focus, as measles was diagnosed in individuals who stayed in the said ski resort [9]. Although these are all single cases, they must evoke certain unrest as they do prove that the threat of a measles epidemic is real, and the freedom of movement additionally enhances the mechanism of disease proliferation. Moreover, the epidemiological situation in countries neighbouring the EU, such as Russia, Ukraine and Serbia, is another source of threat. In Ukraine, whose situation directly affects Poland, there were 4,800 measles cases in 2017, including five deaths, and 2,100 cases in 2018 [10]. In both Ukraine and Romania, which does belong to the EU, the increase in measles incidence is directly correlated with incorrect implementation of immunisation programmes [10]. The situation is made worse by migration, both within and between countries. It renders prognoses concerning new disease foci impossible, which threatens particularly children and individuals who have not been vaccinated [10]. As may be suspected, the mechanisms of measles proliferation from Ukraine to Poland and from Romania to Bulgaria do exist.

Efficacy of vaccination against measles. Immunisation is the basic instrument for combating measles. Measles vaccines became available in 1963-1968 [11]. Before that, it was a common disease with a high mortality rate. In the USA, there were approximately 500 thousand cases of measles annually, mainly among children aged 5-9, of whom about 500 were fatal and approximately 150 thousand were complicated. In Poland, up to the year 1974, nearly all children contracted measles, and the number of cases reflected the birth cohort in a given year [12].

At the beginning of the 1970s, a group led by Maurice Hilleman, an American microbiologist who specialised in vaccinology, developed a combined vaccine against measles, mumps and rubella - the MMR vaccine [11]. Another vaccine used in measles immunisation is MMRV vaccine (against measles mumps, rubella and varicella), which combines an attenuated MMR virus with a varicella vaccine [13].

Immunisation programmes have been implemented in Europe since the end of the 1960s and vaccination is either mandatory or recommended, with the latter also being reimbursed in most cases. The current situation pertaining to measles vaccination is illustrated in Table 2.

Measles vaccination is mandatory in only seven of the 28 EU member states. France and Italy have introduced mandatory vaccination only recently due to the dramatic increase in the incidence. In the remaining EU countries, vaccination is recommended and is usually administered in the first dozen or so months of life, and the second dose given several years later. This scheme was implemented in all European countries up to the year 2000, with exception of Moldova and Azerbaijan [2]. In some countries, adults at 
Table I. Number of cases of measles in the European Union (April 2018 - March 2019

\begin{tabular}{|c|c|c|c|c|c|c|c|c|c|c|c|c|c|c|c|}
\hline \multirow{2}{*}{ Kraj } & \multirow{2}{*}{$\begin{array}{c}2018 \\
\text { Apr }\end{array}$} & \multirow{2}{*}{$\begin{array}{l}2018 \\
\text { May }\end{array}$} & \multirow{2}{*}{$\begin{array}{c}2018 \\
\text { Jun }\end{array}$} & \multirow{2}{*}{$\begin{array}{l}2018 \\
\text { lipiec }\end{array}$} & \multirow{2}{*}{$\begin{array}{l}2018 \\
\text { Aug }\end{array}$} & \multirow{2}{*}{$\frac{2018}{\text { Sep }}$} & \multirow{2}{*}{$\frac{2018}{\text { Oct }}$} & \multirow{2}{*}{$\begin{array}{c}2018 \\
\text { Nov }\end{array}$} & \multirow{2}{*}{$\begin{array}{c}2018 \\
\text { Dec }\end{array}$} & \multirow{2}{*}{$\frac{2019}{\text { Jan }}$} & \multirow{2}{*}{$\begin{array}{c}2019 \\
\text { Fab }\end{array}$} & \multirow{2}{*}{$\frac{2019}{\text { Mar }}$} & \multicolumn{3}{|c|}{ Apr 2018 - Mar 2019} \\
\hline & & & & & & & & & & & & & Total cases & Cases per milion & Total positive cases \\
\hline Austria & 17 & 12 & 6 & 1 & 3 & 6 & 0 & 4 & 1 & 25 & 33 & 1 & 109 & 12,4 & 101 \\
\hline Belgium & 11 & 24 & 22 & 3 & 11 & 14 & 4 & 8 & 7 & 20 & 89 & 68 & 281 & 24,8 & 220 \\
\hline Bulgaria & 1 & 1 & 1 & 7 & 0 & 0 & 0 & 0 & 0 & 0 & 51 & 185 & 246 & 34,6 & 218 \\
\hline Croatia & 1 & 2 & 16 & 3 & 1 & 0 & 0 & 0 & 0 & 0 & 1 & 0 & 24 & 5,8 & 24 \\
\hline Cyprus & 0 & 0 & 0 & 0 & 0 & 0 & 0 & 0 & 0 & 0 & 1 & 0 & 1 & 1,2 & 1 \\
\hline Czech Republik & 40 & 33 & 12 & 4 & 7 & 4 & 7 & 16 & 19 & 47 & 115 & - & 304 & 28,7 & 250 \\
\hline Denmark & 0 & 0 & 0 & 0 & 2 & 2 & 0 & 0 & 1 & 2 & 5 & 4 & 16 & 2,8 & 16 \\
\hline Estonia & 7 & 1 & 0 & 0 & 0 & 0 & 0 & 0 & 0 & 3 & 6 & 2 & 19 & 14,4 & 19 \\
\hline Finland & 0 & 4 & 0 & 0 & 3 & 0 & 0 & 1 & 7 & 3 & 3 & 0 & 21 & 3,8 & 21 \\
\hline France & 619 & 251 & 191 & 81 & 29 & 38 & 76 & 61 & 54 & 124 & 209 & 295 & 2028 & 30,3 & 1093 \\
\hline Germany & 99 & 105 & 94 & 54 & 29 & 24 & 13 & 10 & 10 & 102 & 70 & 123 & 733 & 8,9 & 585 \\
\hline Greece & 352 & 290 & 155 & 38 & 18 & 4 & 2 & 0 & 1 & 0 & 3 & 7 & 870 & 80,8 & 454 \\
\hline Hungary & 0 & 0 & 0 & 0 & 0 & 0 & 0 & 0 & 1 & 2 & 5 & 4 & 12 & 1,2 & 12 \\
\hline Iceland & 12 & 0 & 2 & 5 & 17 & 2 & 1 & 1 & 0 & 2 & 18 & 23 & 83 & 17,4 & 60 \\
\hline Italy & 498 & 461 & 317 & 147 & 79 & 57 & 82 & 58 & 76 & 172 & 160 & - & 2107 & 34,8 & 1646 \\
\hline$\underline{\text { Latvia }}$ & 0 & 2 & 3 & 1 & 1 & 0 & 0 & 1 & 2 & 0 & 0 & 0 & 10 & 5,1 & 10 \\
\hline Lithuania & 0 & 0 & 0 & 1 & 1 & 0 & 0 & 8 & 20 & 12 & 72 & 248 & 362 & 127,1 & 362 \\
\hline Luxemburg & 1 & 0 & 0 & 0 & 2 & 0 & 0 & 1 & 0 & 0 & 0 & 15 & 19 & 32,2 & 19 \\
\hline Malta & 0 & 0 & 0 & 5 & 0 & 0 & 0 & 0 & 0 & 0 & 0 & 3 & 8 & 17,4 & 8 \\
\hline Netherlands & 0 & 3 & 10 & 1 & 4 & 0 & 0 & 0 & 2 & 4 & 4 & 4 & 32 & 1,9 & 31 \\
\hline Poland & 22 & 19 & 12 & 13 & 19 & 9 & 21 & 79 & 114 & 123 & 178 & 219 & 858 & 21,8 & 479 \\
\hline Portugal & 13 & 0 & 3 & 1 & 3 & 3 & 2 & 24 & 12 & 2 & 3 & 2 & 68 & 6,6 & 60 \\
\hline Romania & 111 & 104 & 111 & 100 & 92 & 72 & 65 & 81 & 130 & 261 & 75 & 188 & 1390 & 70,8 & 1092 \\
\hline Slovakia & 3 & 18 & 67 & 257 & 87 & 28 & 16 & 38 & 50 & 43 & 37 & 70 & 714 & 131,4 & 524 \\
\hline Slovenia & 0 & 3 & 3 & 0 & 0 & 0 & 1 & 0 & 0 & 0 & 0 & 0 & 7 & 3,4 & 7 \\
\hline Spain & 50 & 41 & 25 & 15 & 7 & 4 & 4 & 1 & 6 & 11 & 10 & 16 & 190 & 4,1 & 185 \\
\hline Sweden & 2 & 4 & 3 & 3 & 2 & 4 & 1 & 0 & 3 & 0 & 1 & 4 & 27 & 2,7 & 25 \\
\hline United Kington & 202 & 155 & 100 & 82 & 54 & 16 & 21 & 26 & 11 & 71 & 61 & 61 & 860 & 13,1 & 860 \\
\hline Total UE & 2062 & 1535 & 1153 & 822 & 471 & 287 & 316 & 418 & 527 & 1029 & 1212 & 1548 & 1183 & 22,0 & 8396 \\
\hline
\end{tabular}

Elaboration based on European data Centre for Disease Prevention and Control

risk are also recommended to get vaccinated. Vaccination coverage is an indicator of the level of protection against measles in society. It is the percentage of vaccinated people in relation to the entire population (Table 3).

There is a certain relationship between the increase in the incidence of measles in the past years and the level of vaccination coverage. The countries where this phenomenon is observed are those with the lowest vaccination coverage rates; this concerns Romania and France. Both these countries, alongside Belgium, Germany and Poland, for which the vaccination coverage level is higher, have been classified by the WHO as measles-endemic countries. That is why the WHO programme of measles eradication in the European region will not be successful. This conclusion also results from the fact that, according to the data from October 2016, only 13 of 53 countries belonging to the WHO European region declared complete elimination of measles [12]. Despite the efforts undertaken, Europe is not only not free from the disease, but is threatened with a new epidemic.

This, however, does not change the fact that vaccination remains the most effective tool to combat measles, even more so that there is no effective cure [14]. As an example, it is worth adding that according to the epidemiological data of the Polish National Institute of Public Health-National Institute of Hygiene, the incidence of measles in Poland in 2010-2016 did not exceed 0.35/100,000 people [12]. In 1960, there were 255 deaths due to measles, while a decade after the implementation of the immunisation programme (in 1985), this number decreased to 5 . The last fatal case of measles was noted in 1998 [14]. After all, as mentioned earlier, practically every Polish child had contracted measles before vaccines were introduced.

\section{CONCLUSIONS}

The epidemiological problem associated with the incidence of measles has become more serious in Europe in the past years. The WHO-adopted programme assuming complete elimination of measles from the European region has turned out to be impossible to complete. Only 13 countries from this region have declared that their territories have been freed from the disease, whereas 7 European countries, including Poland, are considered endemic areas. This 
Table II. Current immunisation programmes regarding measles in individual EU countries

\begin{tabular}{|c|c|c|c|}
\hline Country & $\begin{array}{l}\text { Vaccination } \\
\text { status }\end{array}$ & $\begin{array}{l}\text { Year of introduction } \\
\text { of mandatory } \\
\text { vaccination }\end{array}$ & Form of vaccination \\
\hline Austria & recommended & & MMR: 1) the first year of life; 2) second dose above 2 years of age \\
\hline Belgium & recommended & & MMR: 1) the first 12 months of life; 2) second dose at 10-13 years of age \\
\hline Bulgaria & mandatory & no data & MMR: 1) $13^{\text {th }}$ month of life; 2 ) second dose: 12 years of age \\
\hline Croatia & mandatory & no data & MMR: 1) $12^{\text {th }}$ month of life; 2 ) second dose: $5-7$ years of age (first-grade pupils) \\
\hline Cyprus & recommended & & MMR: 1) 13-15 months of life; 2) second dose: $4-6$ years of age \\
\hline Czech Republic & mandatory & 1969 & MMR: 1) 13-18 months of life; 2) second dose: $5-6$ years of age; 3 ) booster dose $\geq 18$ years of age \\
\hline Denmark & recommended & & MMR: 1) 15 months of life; 2) second dose: 4 years of age \\
\hline Estonia & recommended & & MMR: 1) $12^{\text {th }}$ month of life; 2) second dose: 13 years of age \\
\hline Finland & recommended & & MMR: 1) 12-18 months of life; 2) second dose: 6 years of age \\
\hline France & $\begin{array}{l}\text { mandatory } \\
\text { in children at } \\
12-18 \text { months; } \\
\text { recommended } \\
\text { for the remaining } \\
\text { groups }\end{array}$ & 2018 & $\begin{array}{l}\text { MMR: 1) first year of life only in the case of a journey to a country at risk; } 2) 12-18 \text { years; } 3 \text { ) second dose for } \\
\text { groups at risk: } 6-17 \text { and } 18-35 \text { years of age; }\end{array}$ \\
\hline Germany & recommended & & MMRV: 1) $11-14,15-23$ months of life; 2) second dose: $2-17$ years of age; 3 ) booster dose $\geq 18$ years of age \\
\hline Greece & recommended & & MMR: 1) 12-55 months of life (if missed: 3 years) 2) second dose: $4-5$ years of age (if missed: 18 and 59 years) \\
\hline Hungary & mandatory & no data & MMR: 1) 15 months of life; 2) second dose: $11-12$ years of age; \\
\hline Ireland & recommended & & MMR: 1) $12^{\text {th }}$ month of life; 2 ) second dose: $4-5$ years of age; \\
\hline Italy & mandatory & 2017 & MMR: 1) 13-15 months of life; 2) second dose: 6 years of age \\
\hline Latvia & mandatory & no data & MMR: 1) 12-15 months of life; 2) second dose: 7 years of age (if missed: after the age of 13 years) \\
\hline Lithuania & recommended & & MMR: 1) 15-16 months of life; 2) second dose: 6-7 years of age; \\
\hline Luxemburg & recommended & & $\begin{array}{l}\text { MMRV: 1) } 12-23 \text { months of life; } 2 \text { ) second dose: } 15-23 \text { years of age; } 3 \text { ) all individuals over } 18 \text { years of age } \\
\text { born in } 1980 \text { who have not been vaccinated }\end{array}$ \\
\hline Poland & mandatory & $\begin{array}{l}\text { 1974; second dose } \\
\text { since } 1991\end{array}$ & MMR in two doses: 1) 11-14 months of life; 2) second dose: 10 years of age (since 2010) \\
\hline Portugal & recommended & & MMR: 1) $12^{\text {th }}$ month of life; 2 ) second dose: 5 years of age \\
\hline Romania & recommended & & MMR: 1) $12^{\text {th }}$ month of life; 2 ) second dose: 5 years of age \\
\hline Slovakia & mandatory & 1969 & MMR: 1) 14-17 months of life; 2) second dose: 10 years of age \\
\hline Slovenia & mandatory & no data & MMR: 1) 12-18 months of life; 2) second dose: $5-6$ years of age \\
\hline Spain & recommended & & MMR: 1) $12^{\text {th }}$ month of life; 2 ) second dose: $3-4$ years of age \\
\hline Sweden & recommended & & MMR: 1) $18^{\text {th }}$ month of life; 2) second dose: $6-8$ years of age \\
\hline United Kingdom & recommended & & $\begin{array}{l}\left.\text { MMR: 1) } 12^{\text {th }} \text { month of life; } 2\right) 3 \text { years of age (individuals over } 16 \text { years of age born in 1997-2003 who have } \\
\text { not been vaccinated }\end{array}$ \\
\hline
\end{tabular}

Source: authors' own analysis based on Vaccine Scheduler

situation is a consequence of a number of factors that have accumulated due to the reduction of the prophylactic role of preventive vaccinations. Countries where this problem has become particularly significant, i.e. Italy and France, have reacted with the enforcing of regulations and introduction of mandatory vaccination against measles. This means that immunisation is still considered the principal tool to combat the disease.

The EU countries, which have been analysed in greater detail, fulfil their national immunisation programmes, where measles vaccination is either mandatory or recommended, but reimbursed from public funds. Most countries offer combined MMR or MMRV vaccines. The vaccination coverage reaches approximately $90 \%$ in all EU countries.

Migration from countries with a high percentage of nonvaccinated people and with a high increase in the incidence, such as Ukraine or Romania, to countries where measles prevention is superior, is also a source of threat within the evaluated region. Tightening the immunisation system and administration of vaccines to non-vaccinated migrants in the target country seem to be the only solutions. In a longer perspective, the scientifically unsupported postulates regarding the autism-inducing effect of MMR vaccine in children may be a factor that will sustain the adverse trends in measles epidemiology. Such postulates may drive antivaccination movements, which will have a destructive effect on the immunisation system that is the most effective shield against an epidemic of dangerous contagious diseases, such as measles. 
Table III. Vaccination coverage for measles in the EU (2017)

\begin{tabular}{cccc}
\hline Country & $\begin{array}{c}\text { Vaccination } \\
\text { coverage }\end{array}$ & Country & $\begin{array}{c}\text { Vaccination } \\
\text { coverage }\end{array}$ \\
\hline Austria & to 84 & Italy & $85-94$ \\
\hline Belgium & $85-94$ & Latvia & $85-94$ \\
\hline Bulgaria & $85-94$ & Lithuania & $85-94$ \\
\hline Croatia & $95-99$ & Luxemburg & $85-94$ \\
\hline Cyprus & $85-94$ & Malta & to 84 \\
\hline Czech Republic & $85-94$ & The Netherlands & $85-94$ \\
\hline Denmark & $85-94$ & Poland & $85-94$ \\
\hline Estonia & $85-94$ & Portugal & $95-99$ \\
\hline Finland & $85-94$ & Romania & to 84 \\
\hline France & to 84 & Slovakia & $95-99$ \\
\hline Germany & $85-94$ & Slovenia & $85-94$ \\
\hline Greece & to 84 & Spain & $85-94$ \\
\hline Hungary & $95-99$ & Sweden & $95-99$ \\
\hline Ireland & no data & United Kingdom & $85-94$ \\
\hline
\end{tabular}

Source: authors' own analysis based on: Vaccination coverage for the second dose of measlescontaining vaccine, EU/EEA, 2017

\section{REFERENCES}

1. Measels, World Health Organization (WHO) https://www.who.int/ news-room/fact-sheets/detail/measles

2. Marchewka AK, Woźniak A, Majewska AG, et al. Progress and problems in the implementation of the eradication and eradication program of measles, rubella and congenital rubella syndrome in the European region. „Forum of Infections” 2017; (3): 219-225.
3. Shang X, Jang J, Xu X, et al. Molecular epidemiology study of measles viruses in Kunming area of China. "Experimental and Therapeutic Medicine" 2017; 5(14): 4167-4173.

4. Szczeklik A, Gajewski P. Interna Szczelika Publishing house. Practical medicine Cracow 2018; 2370-2372.

5. Végh M, Roth HW, Kovacs AH, Facskó A. Ophthalmological symptoms of measles and their treatment. "Orvosi Hetilap" 2017; 158(39): 15231527.

6. Begaydarova RK, Starikov YG, Devdariani KG, et al. The current knowledge of clinical manifestations of measles. "Georgian Medical News" 2015; (239): 63-69.

7. Markel H, Koplik's Spots: The Harbinger of a Measles Epidemic. "The Milbank Quarterly" 2015; (2): 223-229.

8. Cianciara J, Juszczyk J. Infectious and parasitic diseases. CZELEJ, Lublin 2007; 555-560.

9. Communicable disease threats. Report (week 7, 10-16 February 2019). [online: 23.02.2019]

10. Nowak-Starz G, Salwa A, Siwek M, et al. Odor diseases - current epidemiological problem in Poland and in the world. [in:] Asienkiewicz R, Markocka-Mączka K, Biskup M. (ed.), Public health as a standard of well-being, Lublin 2018; 229.

11. Hilleman MR. The Development of Live Attenuated Mumps Virus Vaccine in Historic Perspective and Its Role in the Evolution of Combined Measles-Mumps Rubella [in.] S. Plotkin (ed.), History of Vaccine Development. London: Springer Science \& Business 2011; 207-210.

12. Ściubisz M, Rywczak I. Risk associated with vaccinations and diseases, which they prevent - part of 6: measles, mumps and rubella. [online: 20.02.2019].

13. Vesikari T, Sadzot-Delvaux K, Rentier B, Gershon A. Increasing Coverage and Efficiency of Measles, Mumps, and Rubella Vaccine and Introducing Universal Varicella Vaccination in Europe: A Role for the Combined Vaccine. "The Pediatric Infectious Disease Journal” 2007; (7): $632-638$.

14. Ulicka A, Żak D, Żak J. Measles - etiology, clinical picture, diagnostics and the current epidemiological situation. "Laboratory diagnostician" 2018, (4): 20-22. 